\title{
Franco Volpi, in memoriam
}

El pasado 14 de abril falleció Franco Volpi (1952-2009) a consecuencia de un accidente vial. El profesor Volpi, consejero editorial de Tópicos, profesor de la Universidad de Padua, fue profesor invitado de la Universidad Panamericana en numerosas ocasiones y, sobre todo, amigo entrañable de nuestra comunidad. Lamentamos profundamente su muerte que deja un hueco irreparable entre los estudiosos de la historia de la filosofía.

Volpi fue un intérprete reconocido de Heidegger y editor de sus obras para la Casa Adelfi. Sus libros Heidegger e Brentano (1976) y Heidegger e Aristoteles (1984) son suficientes para hacer de él una referencia obligada entre los estudiosos del filósofo alemán. Además, Volpi editaba la obra de Schopenhauer. Entre las últimas obras de nuestro querido colega se encuentran El nibilismo (2007), Nicolás Gómez Dávila: el solitario de Dios (2005) y Storia della filosofía (con Enrico Berti, de quien fue discípulo, 2008). Una mención especial merece la Enciclopedia de obras de filosofía (2005), monumental obra de la que fue editor en alemán y en francés. 